\title{
Suspect Women: Prostitution, Reputation, and Gossip in Fourteenth-Century Prague
}

\author{
Eleanor Janega \\ Independent Scholar, United Kingdom, \\ eleanor.janega@kcl.ac.uk
}

\section{Abstract}

In the late fourteenth century, Prague was one of Europe's largest and richest cities, having been considerably enlarged under the ruler of the Emperor Charles IV. Though the city was famous as an imperial center and a celebrated place of pilgrimage, this thriving metropolis also boasted several brothels, as well as a community of women engaged in both licit and illicit sex work. This paper will examine attitudes towards women in the Prague Archdeaconate Protocol from 1379 1382, which records dozens of complaints about women who were openly or 'clandestinely' engaging in sex work.

Keywords: Prostitution; Gossip; Prague; Bohemia; Sex Work; Social Grooming; Community; Reputation; Middle Ages 


\title{
Suspect Women: Prostitution, Reputation, and Gossip in Fourteenth-Century Prague
}

\author{
Eleanor Janega \\ Independent Scholar, United Kingdom
}

\section{Introduction}

In the late fourteenth century, the city of Prague was attempting to establish what normalcy would be after decades of unprecedented growth and steady rule. The Emperor Charles IV had died in 1378, after spending the majority of his rule transforming the city from a rundown provincial capital to an impressive imperial capital, and a fitting centre for the monarcha mundi to reign from in perpetuity. ${ }^{1}$ His attentions had seen the city double in size (becoming the second largest city north of the Alps after Paris) as well as gaining its own Archbishopric, gaining freedom from the oversight of Mainz. ${ }^{2}$ As involved as he was in the political life of the city, Charles had also worked extensively to enhance the city's religious reputation. He was close to both the city's first and second Archbishops, Arnošt of Pardubice and Jan Očko of Vlašim. ${ }^{3}$ Indeed, Charles had himself been

${ }^{1}$ Helmut Trnek, The Secular and Ecclesiastical Treasuries, Illustrated Guide, Kunsthistorisches Museum Vienna (Vienna: Kunsthistorisches Museum, 1991), 129. Ferdinand Seibt (ed.), Kaiser Karl IV (1316-1378). Staatsman und Mäzen (Munich: Prestel, 1978), 24.

${ }^{2}$ Fourteenth-century Paris, in comparison, was comprised of 438 hectares. For more on Charles's reinvention of Prague, and the meaning behind it, see: Paul Crossley and Zoë Opačić, "Prague as a New Capital," in Prague: The Crown of Bohemia, ed. Jiři Fajt and Barbara Drake Boehm (New York, New Haven, and London: Yale University Press, 2005), 59-73; Eleanor Janega, Jan Milic of Kromériž and Emperor Charles IV: Preaching, Power, and the Church of Prague (PhD thesis, University College London, 2014).

${ }^{3}$ On Arnošt of Pardubice see: Zdeňka Hlediková and Jana Zachová, Život Arnošta z Pardubic podle Valentina Krautwalda (Das Leben des Ernst von Pardubitz erzählt von Valentin Krautwald) (Pardubice: Východočeské muzeum, 1997). For more on Jan Očko of 
instrumental in securing the post of Archbishop for Jan Očko. ${ }^{4}$ In 1379, Jan Očko stepped down from his responsibilities as Archbishop and died early the following year. After decades of happy concord between the royal and archiepiscopal thrones and a period of unmatched expansion and stability in one of the most important political and religious centres in Christendom, it was time to take stock.

In 1379, Charles's son Wenceslaus (Vaclav) ascended to the Holy Roman and Bohemian thrones, and Jan of Jenštejn succeeded his uncle as Archbishop of Prague. As the new rulers appraised the city, the Archdeacon Pavel of Janovice decided that it was time that the Church speak to the average citizens of Prague in order to ascertain how their religious needs were being met. ${ }^{5}$ The resultant exhaustive visitation protocol which spans the years 1379-1382 reported on a lengthy interview process with representatives from each of Prague's parishes as well as those of the surrounding countryside. What he found was far from Charles's idealised religious bastion. Instead, Prague's citizens lined up to voice their displeasure with issues ranging from poor pastoral care, absentee priests, predatory lenders, and what they called 'suspect women' (mulieres suspectas). The suspect women in question were generally suspected of one thing: engaging in illicit sex work. This was reflected in their other most common labels, meretrices suspectas or occultas. ${ }^{6}$ Several parishes lamented the actions of these women, gave detailed accounts of where the Archdeacon could find them, and asked that the Archdeacon step in to put a stop to their work. ${ }^{7}$

This essay will analyse as its major source the Archdeaconate protocol's complaints about sex work in order to establish how the Church gathered information in Prague and sought to regulate the behavior of those involved - both the subjects of the complaints and

Vlašim see Ferdinand Břetislav, Starožitnosti a památkyẓ̌éčeské (Prague: Kober and Markgraf, 1860), 154-156.

4 See: Fredericus [Bedřich] Jenšovský (ed.), Monumenta Vaticana res gesta Bohemica illustrantia: edidit archivum terrae Bobemiae (Prague: Akademia, 1944), 210 no. 357.

5 Ivan Hlaváček and Zdeňka Hledíková (eds.), Protocollum visitationis archidiaconatus Pragensisannis 1379-1382 per Paulum de Janowicz archidiaconum Pragensem factae (Prague: Akademia, 1973).

${ }^{6}$ For a more specific discussion on the various terms, see David C. Mengel, Bones, Stones, and Brothels: Religion and Topography in Prague Under Emperor Charles IV (1346-78) (PhD thesis, University of Notre Dame, 2003), 238-239.

${ }^{7}$ Hlaváček and Hledíková (eds.), Protocollum, 115-116. 
those making them. In so doing, this paper will act as a case-study of how Prague's residents related to sex work, sex workers, and the men who patronised them. This source provides a unique opportunity to look at day to day life in the capital, as well as to hear opinions on sex work and workers from common people. Most other contemporaneous sources on the subject are either sermons, such as those of the preacher Jan Milíč of Kroměřizz. ${ }^{8}$ However, these sources give us only a specific religious view on the subject, which is at times hyperbolic for rhetorical effect, and gives little clear detail. Prague's municipal records survived in extremely low numbers, and as a result offer few clues to work with regarding sex work and its impact on citizens. Indeed, there is a complete dearth of any public records of sex work in Prague, chartered or otherwise. ${ }^{9}$ Given the almost complete lack of other sources on the subject, the Archdeaconate protocol represents a unique opportunity to study community concerns about sex work, and the way in which they were presented. While at first it may seem reasonable for the plaintiffs in these cases to complain to the Archdeacon about what the perceived to be inappropriate conduct, these complaints in other circumstances could at best be construed as gossip, and at worst as slander. In a society that had for over a century considered the so-called sins of the tongue to be damnable, it is noteworthy that the Church was encouraging its theoretically pious members to repeat common rumors and to name names.

More particularly, it is of note just who it is that is named in these conversations. As this paper will show, while sex workers in general are the common source of complaints, it is not the women themselves who parishioners tended to name. Rather, the plaintiffs regale the Archdeacon with stories about clients who see prostitutes, the people who appear to run houses where they worked, and in some cases, the exact geographical places where women were said to be engaging in 'suspicious' behaviour. An examination of these practices will help establish when people thought it was best to inform the Archbishop of an individual's behaviour, or simply of their generalised sinful conduct.

Following on from this, the remedies that the Archdeacon suggests to solve these theoretical problems will be considered. This essay

\footnotetext{
8 Janega, Jan Milić of Kromerriž and Emperor Charles IV, 79-85.

9 On the survival of records for the brothels, see František, Graus. Chudina Městská v dobvě Predhusitské, (Prague: Melantrich, 1949), 65.
} 
contends that the Archdeacon, on the whole, sought not to intervene with the men that he perceived to patronise or control prostitutes but instead punished women who were connected with sex work. This paper will argue that the Archdeacon considered that there would always be a sort of ambient sexual misconduct at play in Prague. It was therefore up to men to appeal to the godly nature of other men, exhort them to turn away from sin, and to re-establish Christian order. Suspect women, conversely, were to be seen not as individual people to be saved from the sins of lust, but as a sort of destructive force to be curtailed and removed where possible. Men who sinned sexually were thus fallible members of the Prague community. Prostitutes, on the other hand were not community members, but community features.

\section{The Sins of the Tongue and Social Grooming}

Western society, even today, considers gossip to be an overtly negative thing. Gossip is said to be, amongst other things, idle, the resort of small minds, the lowest form of discourse, and - to use a contemporary adage - the Devil's radio. The long-standing objection to gossip in Western society did not have such a long lineage in the medieval period, however. As Edward Cruan has shown, there is a notable increase in concern regarding what the Church termed the sins of the tongue in the thirteenth and fourteenth centuries. ${ }^{10}$ This is reflected in both ecclesiastical and secular writings, but the Church retained an overriding interest in the theoretical problem. After the Fourth Lateran Council of 1215 established the necessity for all Christians to attend confession, there was a proliferation of texts which enumerated the possible sins which could be confessed. These texts often had at least a chapter or more on the various ways in which the soul was imperiled by loose speech. ${ }^{11}$ As Dignan has noted, during this period there is also a notable rise in the number of hell mouths depicted in both visual art and mystery plays, a visible reminder of speech as a road to $\sin .^{12}$

10 Wedward D. Craun, Lies, Slander, and Obscenity in Medieval English Literature: Pastoral Rhetoric, and the Deviant Speaker (Cambridge: Cambridge University Press, 1997).

11 Sandy Bardsley, "Sin, Speech, and Scolding in Late Medieval England," in Fama: The Politics of Talk and Reputation in Medieval Europe, ed. Thelma S. Fenster and Daniel Lord Smail (Ithaca, N.Y. and London: Cornell University Press, 2003), 146.

12 Patricia Dignan, Hellmouth and Villains: The Role of the Uncontrolled Mouth in Four Middle English Mystery Plays (PhD thesis, University of Cincinnati, 1994). 
The idea that loose talk was a sin was tied to the fact that one's reputation was paramount in medieval society. Throughout the period, societies in many regions relied on reputation to establish whether an individual would make a trustworthy business partner and a reliable, respectful community member. ${ }^{13}$ Men, from a legal standpoint, owned their good name as a possession until it was taken from him. Often, losing one's good name had specific legal consequences and such individuals would be avoided by anyone hoping to take part in public life. ${ }^{14}$ If one relied on their good name to take part in society, and if the loss of reputation was a specific legal punishment, then it was important that private individuals be prevented from damaging the reputation of others. The condemnation of individuals was the sole preserve of either the Church or the local judiciary.

Gossip in medieval society was therefore a theoretically destructive activity that had to be curtailed lest individuals be unfairly cast out of their community. The evolution of gossip, however, was arguably brought about for the exact opposite reason - the creation of social cohesion. As Dunbar has contended not only gossip, but '...language evolved as a mechanism for binding large social groups, and ... it does so precisely because it allows us to exchange information about the state of our social networks. ${ }^{3}{ }^{15}$ s a result, gossip did not initially have a negative meaning. 'It meant simply the activity that one engaged in with one's "god-sibs", one's peer group equivalent of godparents: in other words, those with whom one was especially close.' ${ }^{16}$ Furthermore, Dunbar posits that language itself was invented by humans as a substitute for social grooming that lends social cohesion to other groups of primates. Because there is an upper limit to the time that can be spent grooming, there is necessarily an upper limit to the group size of primates that rely on it to create social bonds. Language therefore was developed as 'an alternative mechanism for bonding in which the available social time was used more efficiently. Language appears to

${ }^{13}$ F.R. P. A. Kehurst, "Good Name, Reputation, and Notoriety in French Customary Law," in, Fama, ed. Fenster and Smail, 75.

14 Ibidem, 79.

15 R. I. M. Dunbar, “Gossip in Evolutionary Perspective," Review of General Psychology 8.2 (2004): 110 .

16 Ibidem, 100. 
serve that function perfectly, precisely because it allows a significant increase in the size of the interaction group. ${ }^{17}$

Indeed, the fact that the Church felt the need to condemn gossip is testament to how compulsive the practice was, as well as the role that it played in human society. It allows one to prove that they are part of a social group by showing their intimate knowledge of the individuals which make it up. Despite the fact that the Church condemned gossip, it is clear from the very existence of the Archdeaconate visitation protocol that it nevertheless was reliant on gossip to know when to intervene with certain individuals. If a sinner could not be compelled to confess their faults and their faults were obvious enough, then it should be possible for the Church to correct them nonetheless. Moreover, if gossip is accepted as a stand in for social grooming, so too can the exchange of intimate knowledge for the purpose of correction be understood as a form of social grooming itself. In the case of the Archdeaconate visitation protocol, we can see sexual misconduct as a theoretical offending parasite to be removed. Dunbar's theory of social grooming is therefore useful for this study, as well as any studies involving communal discussion of people and their actions, in that it allows us a way to understand the behavior itself, rather than simply analysing the language employed. It is this theory which this case study will employ on the community of late medieval Prague. Dunbar's theory is useful for medieval discussions because it builds on other forms of mediated reference theory, and posits a specific link between language and behavior, and the end goal of social discussions. In so doing it will allow the chance to critique the behavior - the social grooming - behind the Archdeaconate discussions, rather than the meaning of the language in isolation.

In addition, the involvement and encouragement of the Church in the gossip of priests and parishioners in and of itself lends authority to the practice. It is acceptable to discuss the sexual transgressions of members of one's parish in this instance because you are doing so with the understanding that the Church will remedy the situation. In this way, the act of gossip functions as a sort of confession for the parish as a whole. The plaintiff, by reporting on sexual impropriety and suspect behavior, can thus rid his or her community of the blight of sin, in

17 Ibidem, 102. 
effect cleansing or grooming it. In so doing, the plaintiff can simultaneously prove him or herself as a part of the social group of the parish. Likewise, those who reported to the Archdeacon were also proving themselves as model members of Christendom as a whole. They were aware of sinful behaviour, reviled it, and were willing to do what it took to cleanse their community of it. The plaintiffs were grooming not only their own society, but the Christian faith as a whole.

\section{Civitas Pragensis}

The Archdeacon's visitation was a lengthy undertaking, in part because of the dense network of parishes in fourteenth-century Prague. At the time, Prague was home to around forty-thousand inhabitants. ${ }^{18}$ These citizens were sorted into forty-five parishes, though these were hardly the only places of worship within the city. The city was also home to several monasteries and nunneries, many of which had been personally endowed by the late Charles IV. By any measure, the city was an impressive one both in size and in terms of its religious network. As a result, it was not only the religious organizations which saw to the needs of the populace.

Prague in the late fourteenth-century was, like any other large medieval city, also home to a host of sex workers. As a rapidlyexpanding city, Prague's sex workers had no shortage of potential clients. The trade was accessible enough that women who arrived in the city unaccompanied could find lucrative remuneration if they lacked other skills. Life in the capital was notably expensive, with the costs of housing and fuel increasing due to local shortages of wood. ${ }^{19}$ Groceries were also often prohibitively expensive, and many citizens complained that poorer customers were often charged a higher price for essentials that their well-off counterparts could afford. ${ }^{20}$ Life in Prague for many

\footnotetext{
18 Exact population figures for fourteenth-century Prague are, like those of most medieval cities, disputed. Most historians accept the hypothesis that the city was home to an impressive 40,000 inhabitants as argued by Jaroslav Mezník in, "Der ökonomische Charakter Pragsim 14. Jahrhundert,” Historica 17 (1969): 45-47, 81-83.

${ }^{19}$ Josef Šusta, Karel IV. Za císařskou korunou, [Charles IV: For the Imperial Crown] Vol. II, Ceské Déjiny [Czech History] (Prague: Jan Laicher, 1948), 206.

20 See: John Martin Klassen, The Nobility and the Making of the Hussite Revolution (New York: East European Quarterly, 1978), 21, 23; Graus, Chudina Městská, 86-88, 98.
} 
women was thus made feasible through the relatively lucrative sex trade.

Some of Prague's sex workers, unfortunately, had less of a say in their trade. It was common practice for moneylenders in Prague to insist that unpaid debts be compensated through labour at the time. After making such an agreement and falling into arrears, female debtors learned that the labour in question was sex work. For example, one such case survives in which the unfortunate Dorothy of Strygl found herself indebted to the madam Ann Harbatová in a contract which required her to work until her debt was repaid under pain of death. ${ }^{21}$ Brothels in the city also used the same method for acquiring new workers, a practice common enough that records from 1395 relate that a madam was loaned fifty groschen by a town official to keep her operation afloat. ${ }^{22}$

Women who either elected to take up or found themselves in sex work had at the time of the Archdeacon's visitation two municipal brothels in which they could legally work: Hampays in the Old Town, or Obora near the castle. ${ }^{23}$ The city, like any major metropolis, had need of such institutions lest the lust of Prague's men build to uncontrollable levels and give rise to violence. ${ }^{24}$ Prague's brothels served the community and adhered to medieval cultural norms in terms of location as both were placed on the edges of the city. As can be seen on Figure 1, Hampays was located very near to the Vlatava, in the northwestern part of the Old Town in an area known for its bathhouses. Obora, meanwhile, abutted the city wall in the northwestern part of the Lesser Town, near the city gates. (Again, see Figure 1). ${ }^{25}$ While these brothels were able to continue their work, those which fell afoul of cultural norms did come under scrutiny. The largest brothel in the city had been Venice, which had stood near the

\footnotetext{
${ }^{21}$ Klassen, The Nobility and the Making of the Hussite Revolution, 258.

22 Graus, Chudina Mèstská, 67, 106.

${ }^{23}$ For more on these institutions, see: Mengel, Bones, Stones, and Brothels, especially pages 218-243 and Janega, Jan Milić of Kroméríz and Emperor Charles IV, especially pages 79-85 and 102-110.

${ }^{24}$ For more on the nuanced position of sex workers in medieval society, see: Ruth Mazo Karras, "Prostitution in Medieval Europe," in Handbook of Medieval Sexuality, ed. Vern L. Bullough and James Arthur Brundage (New York and London: Routledge, 1996), 244-247.

${ }^{25}$ For the locations of both brothels see Fig. 1.
} 
Old Town city wall. However, when Charles IV created the New Town the brothel was suddenly in the center of town. As a result, it was converted to a religious institution, called Jerusalem, by the preacher Milíc of Kroměřizz, with the approval and financial support of the Emperor. ${ }^{26}$ Thus, while sex work was ingrained enough into the city of Prague that officials would financially speculate on it, there were limits to what the locals found acceptable.

These limits are recorded in the visitation protocol, and within the limits of Prague itself some twenty-one parishes felt that they had cause to complain about what they perceived as abuses. It is of note that while, in theory, there were locations in Prague in which sex work was acceptable, parishioners in those same locations did not always share that sentiment. Even though it was chartered, Hampays '.... a place in which public and communal access to a brothel [was] had...', was the subject of a number of complaints. ${ }^{27}$ Similarly, a certain Master Ulrich, perhaps in emulation of the late Jan Milíc , noted to the Archdeacon that he had tried on several occasions to shutter the Obora brothel, but that the sex workers there always managed to return there '... because they [were] favoured by the judge of the city.' 28 Similarly, complaints

${ }^{26}$ For Jerusalem's location see Fig. 1. For more on Jerusalem, see: Janega, Jan Milic of Kromériž and Emperor Charles IV, 102-110.

27 The parishioners of St. Valentine's church, for example complained about Hampays, stating '... that there is a place called Hampays, in which public games of ball and dice are played on feast days and others, daily, year round, a place in which public and communal access to a brothel is had, and it is said about the same that in that place there is never a year when two or more men are not killed.' ('...quod est quidam locus dictus hampays, in quo publicus ludus globorum et taxillorum diebus festivis et aliis cottidie per circulum anni, in quo loco eciam est prostibulum publicum et communis accessus habetur ad easdem et dicit, quod in eodem loco nunquam est annus, quo non interficiantur duo ultres homines.'), Protocollum, ed. Hlaváček and Hledíková, 82. See Fig. 1 for the location of Hampays, on the right bank of the river, as per this complaint. 28 'Dominus Ulricus ... interrogated under oath said, that there is a certain place before the gates of public women prostitutes, which the patricians on his petition sometimes act to expulse, but they always return to that same place because they are favoured by the judge of the city; [and] that place is called in the vulgar Obora'. ('Dominus Ulricus...interogatus per iuramentum dicit, quod est quidam locus ante valvam mulierum publicarum meretricum, que aliquociens fuerent expulse ad peticionem suam per scabinos et semper revertuntur ad eundem locum et ibidem foventur per iudicem civitatis; qui locus in wlgaridicitur Obora.'), Protocollum, ed. Hlaváček and Hledíková, 118. See Fig. 1 for the location of Obora, next to the city gates near the castle, as per this complaint. 
from parishes in the corners of the city, such as Sts. Simon and Jude in the Old Town, or St. Pancras in Vyšehrad (both shown in Fig. 1) show that while sex work might be taking place in the areas it was traditionally relegated to, it was still seen as an evil to combat.

As the map at the end of this article shows, however, there was no quarter of Prague in which parishioners did not complain about sex work. Each of the named parishes on the map had at least one complaint about sex workers in its vicinity. Thus, while city officials may have considered sex work reputable enough to invest in, and felt that it was regulated in a sufficient enough manner to have municipal backing, ordinary members of the public felt that there was much more that ought to be done to control the practice. If the magistrates would not listen, and indeed profited from sex work themselves, the citizens would appeal to a greater authority - the Church.

\section{'...quod publice famatur...' The Subjects of the Complaints}

As the accusations about sexually available women within the Archdeaconate visitation protocol are examined, they yield interesting results. Although there are dozens of complaints about the suspicious activity of women, it is rarely individual women who the plaintiffs are asking the Archbishop to intercede with. Rather, in the great majority of cases parishioners and priests are either complaining about the actions of men in general, or specifying the buildings or locations in which they believe sex work was occurring. Many of the complaints are aimed at specifically named men. Yet, that these men were seeing suspect women or secret prostitutes was never in and of itself the issue that concerned the plaintiffs. Rather, in order for a man to be denounced for consorting with these women, he was usually a member of the clergy, married (and therefore had no licit use for sex work), or actually participating in organizing sex workers.

For example, in the parish of St. Andre the greater [Ondřej Velky] which can be seen on the map in the Old Town, somewhat near the river, one Thomas Tele complained that a gardener named Jaxo was living in a 'common house' with women who were secret prostitutes. ${ }^{29}$

$29^{\circ}$ Thomas called Tele, a Prague citizen and parishioner of the aforesaid church of St. Andre, swore and said when asked ... that a certain Jaxo the tailor staying in the aforementioned parish, has women [who are] suspected prostitutes...' ('Thomas dictus 
In theory, Jaxo, as an apparently unmarried man, was free to consort with sex workers. Indeed, it would even be possible for him to stay in one of Prague's licensed municipal brothels. In fact, Prague's magistrates had such a staunch belief in the necessity of municipal brothels that the aforementioned Master Ulrich complained to the Archdeacon that every time he tried to force the women of Obora to leave, they went straight to the city magistrates and were escorted back to the premises. ${ }^{30}$ The problem with Jaxo, then, was not that he was consorting with sex workers, but that he was doing so outside of a licit institution, running a de facto unlicensed brothel.

Men living with women and running small unlicensed brothels is a recurrent theme throughout the visitation protocol. In the same parish, there were several complaints that a soldier named Wenceslaus (Vaclav?) Borowski had several 'women [who are] secret prostitutes' at his house 'every day' and that a certain Jindřich called Kluk was keeping 'secret prostitutes' in his home. ${ }^{31}$ In the parish of St. Gallen [Havel],

Tele, civis Pragensis, parrocianus ecclesie sancti Andree predicte, iuratus et interrogates dicit ... quidam Jaxo sartor, morando in plebe predicta, teneat mulieres occultas meretrices...'), Protocollum, ed. Hlaváček and Hledíková, 71.

30 Ibidem; Vladivoj Tomek (ed.), Základystarého starébo mistopisu pražskébo, Vol. 3, (Prague: Královská česká společnost nauk, 1886), 78, no. 242. Master Ulrich registered his complaint in his capacity of parish priest for St. Nicholas [Mikuláše] church in the Lesser Town. See Fig. 1.

31 'Andreas called Typarz, a parishioner of said church, said, that Wenceslaus, a soldier, called Borowski, has a house in the aforementioned parish, in which women [who are] secret prostitutes are accustomed to convene every day, and through summons and testimony and later following warnings, he is often told to desist, but he doesn't care.' ('Andreas dictus Typarz, parrochianus dicte ecclesia ... dicit, quod Wenceslaus, miles, Borowski dictus, habeat domum in plebe predicta, quam quotidie soletta libus mulieribus meretricibus occultis convenire, et sepius est per dictum testem et precedentem et infra sequentem monitus ab hoc desistere - non curat.') Protocollum, ed. Hlaváček and Hledíková, 71; 'Velislaus the brewer ... said that [with] Jaxo, described above, and in a house of the parish opposite the church, the name of which he does not know, and in house of master Jindrrich called Kluk, described above, there are secret prostitutes...' ('Velislaus brasiator ... dicit, quod Jaxico, de quo supra, et in domo plebani ex oposito ecclesie, de cuius nomine ignorant, et quod in domo domini Henrici dicti Kluk, de quo supra, sunt mulieres oculte...') Ibidem, 72; 'Troianus the brewer, said that Wenceslaus called Borowsky, mentioned above, and in the house of Master Henry, described above, and in a certain house across from Hodson the brewer, namely in the house of Stoklason, there are women [who are] secret prostitutes.' ('Troianus brasiator ... dicit quod Wenceslaus dictus Borsowsky, de quo supra, et in domo domini Henrici, 
seen on the map in the Old Town near the square, Wenceslaus Lopata was essentially running an illicit brothel by 'supporting' sex workers to whom there was 'communal access' in his home, much to the scandal of his neighbors. ${ }^{32}$ Overall, the named men were thus denounced not as mere lustful sinners, but as unlicensed sex traffickers, a much more grievous offense.

Similarly, members of the clergy were a frequent subject of complaint within the visitation protocol. Prague's priests, it would seem, were capable of the same sort of excess as their parishioners; distressed plaintiffs at St Mary of the Lake [Marie jezera] begged the Archdeacon to intercede with priests who went as far as to allow suspect women to offer gambling as part of their services within the parish. ${ }^{33}$ In one notable case, a priest named Ludwig Coiata from the parish of St. John on the Rocks [Jan Podskali], located in the south of the New Town (see Figure 1), was living with 'sometimes four, sometimes six, sometimes eight public women, to whom there is communal access of men, all of which neighbours and people passing by stumble upon and are scandalized' and 'had twice fled naked from the judges through the New Town of Prague, and scarcely escaped to his home' when confronted about his misdeeds. ${ }^{34}$ At the church of St.

de quo supra, et in quandam domo ex opposite Hodsonis brasiatoris, videlicet in domo Stoklasonis sint mulieres occulte meretrices.') Ibidem.

32 'Martin of Libeň, a priest in his second year, said that Wenceslaus of Long Street, called Lopata, supports women prostitutes in his house, to whom there is communal access, and men are scandalized by that.'('Martinus de Lybun, presbyter in secondo anno ... dicit, quod Wenceslaus de Longa platea dictus Lopata fovet in domo sua mulieres meretrices, ad quas est access communis, per quod homines scandalizantur.') Ibidem, 86.

33 'He then said, that near the parish of St Leonard, many priests convene with suspect women outside where they would sometimes take comfort in exercise, and play at dice and gambling.' ('Item dicit, quod circa plebanum sancti Leonhardi, ... solent convenire plures presbyteri cum mulieribus suspectis, ubi sua solent solacia exercere interdum et taxillos ludunt et in alea.') Ibidem, 77.

34 'He then said that master Ludwig called Coiata, had twice fled naked from the judges through the New Town of Prague, and scarcely escaped to his home, which is across from the school of St Apollinaris, in which he is accustomed to foster sometimes four, sometimes six, sometimes eight public women, to whom there is communal access of men, all of which neighbours and people passing by stumble upon and are scandalized.' ('Item dicit, quod dominus Ludvicus dictus Coiata ... quod bina vice fuit per iudicem Nove civitatis Pragensis nudus fugatus, quod vix ad domum suam, que est versus scolas sancti Appollinaris, evasit, in qua stolet interdum IIII ${ }^{\text {or }}$, interdum VI, interdum VIII ${ }^{\circ}$ 
Giles [jili1], other priests were said to allow the construction of wooden structures around their churches and in their cemeteries under which 'sexual intercourse [was] often committed. ${ }^{35}$ That is to say, they were creating makeshift brothels for women to work in. When they were not busy living with and creating business opportunities for sex workers, many priests simply saw prostitutes on a professional basis. So pervasive was the patronage of prostitutes by clergymen in the city and surroundings that when one priest was confronted about his dealings with a prostitute, he attempted to assuage the wrath of the archdeacon by insisting that he only saw her from time to time at night, and sent her away first thing in the morning as soon as she was paid. ${ }^{36}$

It is therefore clear that for the majority of Prague's residents, men seeing sex workers was not a sufficient enough problem to ask for the Archdeacon to intervene. In general, the theoretical sin which needed extricating from their community to a sufficient degree to make a complaint had to be individuals patronising prostitutes despite vows of celibacy, or the organisation of sex workers in a non-licit way. Prague's citizens complained not that men were seeing licit sex workers, but that priests were; not that men were staying in brothels, but that they were keeping illegal ones. To break the taboo against gossiping, even in a setting which encouraged it, parishioners needed a sin worth gossiping about; a notable nuisance to the community thus needed to be removed.

mulieres publicas fovere, ad quas est communis accessus hominum, de quo vicini et omnes homines transeuntes scandalisantur.') Ibidem, 48-49.

The title 'On the Rocks' of the St. John's church likely refers to the Podskalí neighbourhood, in the south of Prague's New Town, bordering on Vyšehrad. The St. John church is no longer extant, and this study cannot pin-point the exact location of the church, but has identified the most probable location. See Fig. 1.

35 ' $\mathrm{He}$ then said, that they set wood in the cemetery around the church, under which bitter carnal commingling is often committed and he heard that permission had been given from the deacon, and, he had heard, the parish.' ('Item dicit, quod ponuntur ligna in cimiterio et circum ecclesiam, sub quibus acerbis carnales commixtiones sepius committebantur et commituntur [sic], ut audivit, et hoc ex permissione decani, ut audivit, et plebani.') Ibidem, 53.

36 'Wenceslaus of Zap, a priest, said that he occasionally comingled at night with a public woman and first thing in the morning after paying, he dismissed her.' ('Wenceslais de Zap, presbyter ... dicit, quod ipse interdum commiscetur una nocte mulieri publice et statim de mane, soluto precio, ipsam dimittit.') Ibidem, 254-255. 
In contrast to the voluminous complaints made against named men, and despite the fact that the complaints centre upon the theoretical licentiousness of women, the analysis of this document indicates that there were very few complaints which go as far as to name specific women. In fact, of the complaints about sex work studied, only five women are named as participating in illicit sexual dealings: a Mara, a Polka, a Vela, an Ela, and a Domka. The women in question share certain traits; the complaints against them are several. Though the women were infamous, none of the plaintiffs seem to have known enough about them in order to provide last names (in contrast to most of the men who were the subject of complaints). All of the women were accused of running clandestine brothels.

Mara, apparently in the house and company of a man named Wilhelm of Skala, was living with a group of secret prostitutes in the parish of Sts. Jacob and Phillip the apostles, situated in the present-day Zlíchov area, in the south of the city on the eastern bank of the Vlatava. Though they were outside of the metropolitan bounds of the fourteenth-century city, as can be seen on the map below, they were nevertheless adept at inducing 'married men and priests to commit fornication' in great enough numbers to cause a stir. ${ }^{37}$ Polka had moved to the same parish sometime around the feast of St. Gall, or October the sixteenth, and set about running her own house of secret prostitutes, to the scandal of the locals. ${ }^{38}$ Vela and Ela were each living in their own house in the parish of St. John the Baptist, located in the southern part of the Lesser Town, as can be seen on the map. There, each presumably organized a group of several other unnamed secret

\footnotetext{
37 'He then said, that he has a certain widow named Mara, who was staying in the home of Wilhelm of Skala, who constantly fosters women [who are] secret prostitutes, who induces married men and priests to commit fornication in the same house.' (Item dicet, quod habeat quandam viduam nomine Maram, que moratur in domo domini Wilhelmi de Skala, que continue fovet mulieres occultas meretrices, que inducit maritatas in dictam domum et presbyteros, quas dicta domo publice permittit fornicari.') Ibidem, 69.

38 ' $\mathrm{He}$ also says, that there is a certain Polka staying in the parish, of who it is said, and heard, that she has secret prostitutes also who she has willed to move to the parish after the feast of St Gall.' ('Item dicit, quod in plebe sua predicta moretur quedam Polka, de qua dicitur, ut audit, quod teneat eciam occulte meretrices, que post festum sancti Galli se wlt de dicta plebe sua trasferre.') Ibidem.
} 
prostitutes in close proximity to the castle. ${ }^{39}$ Meanwhile, Domka was the wife of one of King Wenceslaus's chamberlains, but was living in the house of one Henry [Jindrich] in the parish of St. Andre the Greater. There she was said to live with other suspect women whilst apparently blessing and administering herbs to men complaining of head ailments and blindness. ${ }^{40}$

The complaints against Domka are of particular interest to this study, because unlike Marka, Polka, Vela, and Ela, the complaints about her and her household can be construed in a number of ways. She herself seems to have become the subject of gossip for living in the company of a group of 'suspect' women in Henry's house, despite being married to someone else. The most specific of the complaints against her does not indicate that she is engaged in the sex trade herself. Quite to the contrary, she appears to have been a woman of some means who is providing medical services, though admittedly unorthodox ones. Still, she and her cohorts are referred to in much the same way that plaintiffs spoke of communities of women who were selling sex in an explicit manner. In this instance, it is impossible to know whether Domka and her companions were engaged in sex work.

39 'He then said, that there are a certain two women, one of which is called Vela and the other Ela, who have houses in said parish, which have women [who are] secret prostitutes.) 'Item dicit, quod sint quedam duo mulieres, quarum una vocatur Vela et alia Ela, que habeant domos in dicta parrochia, que tenant mulieres occultas meretrices.' Ibidem, 74 .

'He also said, that in his parish there were two houses of many women [who were] secret prostitutes, who were publically visited by men, and by who many men were scandalised.' ('Item dicit, quod sint in plebe sua due domous vel plures mulierum ocultarum meretricum, que publice per homines visitantur, de quo multi homines scandalisantur.') Ibidem.

40 'He then said, that a certain women named Domka, praying for the deaf in the house of master Henry, as explained below, has suspect women.' ('Item dicit ... quedam mulier Domka nomine surdam orando in domo domini Henrici, de quo infra, tenet mulieres suspectas...') Ibidem, 71. 'He also said, that a certain Domka, the wife of Wenceslaus the chamberlin of the king of Bohemia, who was staying in the house of master Henry, the rector of the school of law of the University of Prague, is accustomed to bless the heads of certain men when they are in pain, and cures men in another way with the many virtues of herbs, and it is said, the blind.' ('Item dicit, quod quedam Domka, uxor Wenceslai camerarii regni Boemie, que moratur in domo domini Henrici, rectoris universitatis iuristarum studi[i] Pragensis, que solet benedicere capita hominum quando dolentur, et aliter solet homines curare multi mode virtute herbarum, quam dicit esse cecam.') Ibidem. 
What is clear, however, is the very act of living together and providing a service without male oversight seems to have set locals talking. Any woman capable of selling services in order to support herself and living in common with other women may as well have been selling sex. When a woman engaged in business in this manner, it was seen to have an inherent sexual bent simply by virtue of the gender of those engaged in it. The plaintiffs made it clear that they felt that Domka was a woman worth engaging in talk about, and they seemed to have thought that the Archbishop should do something about her.

Though specific men and women were the targets of complaints about prostitutes, the largest number of complaints were made not about individuals, but rather about locations in which sexual activity was thought to be happening. Joining the aforementioned Master Ulrich's (futile) complaints about Obora were complaints about Prague's other licit brothel (Hampays) along with baths, houses, bushes, and most notably 'that there [was] an entire street of ... suspect women, which is named Krakow street'. ${ }^{41}$ The complaints about the

41 ' $\mathrm{He}$ also said, that there is one house in line on the street, where the turn to the bath of St Francis [is], where Peter the painter stays; in that place women [who are] secret prostitutes are fostered by him, to whom there are communal access, and many are scandalized by that.' ('Item dicit, quod est domus una in acie in platea, ubi transitur ad balneum sancti Francisci, ubi Petrus pictor morator; ibidem per ipsum foventur mulieres oculte meretrices, ad quas est communis accessus, per quod homines scandalizantur.') Ibidem, 97. The baths of St. Francis were near the Old Town side of the bridge. See Fig. 1. 'And he said, that in the parish church across from the baths near the river, public women convene and stay in a house, in which there is communal access.' ('Item dicit, quod in parrochia ecclesia versus balneum circa flumen mulieres publice converunt domum et morantur, ad quas est communis accessus.') Ibidem, 85. This complaint may refer to the parish of the Church of Sts. Simon and Jude, which was near the river, and close to one of Prague's authorised brothels - Hampays, which had baths and was located near the Vlatava and the Jewish quarter. See Fig. 1. 'He also said, and heard, that at the benefice of St. Leonhard public women very often enter, and other different monks and other priests and they make there their assemblies and comingle, and, he heard, that the greatest scandal is committed there in the benefice and to the villainy of the public.' ('Item dicit, ut audivit, quod ad dotem sancti Leonhardi sepissime intrant mulieres publice et alie diverse etiam monachi et presbyteri alii et faciunt ibidem conventicula eorum et commiscentur et, ut audivit, quod maxima scandal committuntur ibidem in dote et nequicie publice.') Ibidem. The parish of St. Leonard was located in the Old Town. See Fig. 1. 'And he said, he heard, that it was common knowledge that at the benefice of St Nicholas, women [from] far and wide] entered on the other side of the hedge ... and they commingled with priests, and clerics and very often.' ('Item dicit, ut audivit, quod publice famatur, quod ad dotem sancti 
places in which illicit sex (and sometimes licit sex, as in the cases of Obora and Hampays) were taking place, or the newly arrived groups of women perceived to be offering it are too numerous to recount in detail in this paper; but this in and of itself is instructive. The Praguers interviewed by the Archdeacon were obviously more comfortable recounting gossip when a particular individual could not be singled out for disrepute. Complaints about an area where illicit sex was taking place allowed parishioners to prove their knowledge about their community, as well as their dedication to its social hygiene. Whether this is evidence of a proclivity for gossip of a more nebulous sort in general, or simply an indicator that pious Christians, even with the blessing of the Archdeacon, were wary of being accused of tarnishing the reputations of others, is difficult to tell. What is certain, however, is that when the possibility of damaging an individual's reputation is taken off the table, the citizens of Prague were much more likely to talk.

\section{'...dominus archidiaconis mandavit...' The Archdeacon's Remedies}

In some instances when plaintiffs approached the Archdeacon, he gave swift and decisive judgments on how to remedy the problems at hand. Once again, the Archdeacon's punishments and the manner in which they were apportioned are instructive. On the whole, if a prescribed punishment exists for men who were the subject of complaints, it was generally penance. Wenceslaus of Zap, the priest who was punctilious enough to send sex workers away after paying them, was told to pay a fine, lest he face excommunication and suspension. ${ }^{42} \mathrm{~A}$ priest who had

Nicolai ex alia parte sepe intrant mulieres vage et alie ... cum presbyteris et clericis et quod sepius eciam commiscentur.') Ibid. This complaint was made in the parish of St. Castulus in the Old Town. See Fig. 1.

'He also said, that there is an entire street of these suspect women, which is named Krakow street.' ('Item dicit, quod habeat unam plateam integram de istis mulieribus suspectis, que platea Krakovia nuncupatur.') Ibidem, 62. Krakow Street was and is located in the New Town. See Fig. 1.

42 In that place the master Archbishop commanded this same parish priest that two [payments] of sixty, which he had confessed ... be bestowed upon his church and pay the said sixty as two, one on the feast of St George, and the other on the upcoming feast of St Gall, under pain of suspension from entering the church, as promised.' ('Ibidem dominus archidiaconus mandavit ipsi plebano, ut duas sexagenas, quas confessus est ... inpendat super ipsa ecclesia et quod solvat dictas sexagenas duas, 
been seen entering a brothel of secret prostitutes was asked to promise the Archdeacon that he would not play dice or spend time with 'suspect women', and even threatened with incarceration for a month if he failed to do so. ${ }^{43}$ Punishment in both these cases was thus more or less suspended, provided that the men mended their ways. Many of the men, even those men like Wenceslaus Borowski who attracted multiple complaints, did not seem to have been objects of enough concern to the Archdeacon to attract a recorded punishment. The aforementioned Wenceslaus Longa, who was living in what constituted a brothel in the parish of St. Gall escaped any recorded punishment, though the Archdeacon had taken the time to record advice on and appropriate punishment for a woman living as a concubine with a priest in the same parish. Not even Ludwig, the naked fugitive priest, received a recorded punishment from the Archdeacon, despite complaints not only about his sexual behaviour, but his poor pastoral care as well.

Women, in contrast, received specific and immediate punishment. Whereas Wenceslaus of Zap was given the opportunity to repent, Mara, the industrious madam working alongside Willhelm of Skala was excommunicated. ${ }^{44}$ Willhelm himself does not have a recorded punishment, despite the fact that he was also living in an illicit brothel. Polka seems to have been somewhat luckier than Mara. Rather than a

unam in festo sancti Georgii et alterum in festo sancti Galli festorum proxime venturorum sub pena suspensionis ab ingressu ecclesie, quod promisit.') Ibidem, 255.

${ }^{43}$ Michael of Benesov ... he said, who in this present year he saw at the parish of the blessed Mary enter a house in the parish of St Castulus, in which there are secret prostitutes.

He promised at the had of the master the archdeacon that he would not play dice and not hold himself to suspect women under pain of imprisonment for one month.' ('Michael de Benessow ... dicit, quod anno presenti vidit plebanum prescriptum beate Marie intrare domum in plebe sancti Castuli, in qua sunt occulte meretrices. Ibidem pomosit ad manus domini archidiaconi, quod ipse non lude taxillos et non tenebit se ad mulieres suspectas sub pena carcerum pro uno mense.') Ibidem, 105.

44 'The year of our lord 1380, twentieth day of March, the thirteenth hour at the front of the great church of Prague, Mara Mulier, domestic of the house of master Willhelm of Skala in the Greater Town of Prague, the sentencing of excommunication for the reason of her broad contumacy by master Paul, the archdeacon of Prague, is absolute.' ('Anno domini MCCCLXXX, die XX mensis Marcii, hora terciarum antes fores maior ecclesie Pragensis, Mara Mulier, domestica domus domini Wilhelmi de Skala Maioris civitatis Pragensis, a sentencia excommunicacionis in ipsam racione sue contumacie lata per dominum P[aulum], archidiaconum Pragensem, est absoluta.') Ibidem, 70. 
full excommunication, the Archdeacon simply let it be known that she and her secret sex workers could be ejected from the parish. ${ }^{45}$ Velka and Ela appear to have met the same fate as Polka. The Archdeacon announced that the women in the suspected houses could be expelled from their homes and the parish. ${ }^{46}$ There is no recorded punishment for the mysterious Domka, though what it was she was actually doing and whether it was dire enough to require censure or simply odd enough to attract gossip is difficult to say. It is notable, however, that while the visitation protocol records the names of dozens of men accused of sexual impropriety, it is a struggle to find records of their punishment. Four of the five accused women, on the other hand, were summarily punished immediately.

Yet it was not only individual women who managed to attract punishment from the Archdeacon. At times, he ordered for entire swathes of women, whose major crime appears to have been being 'suspect' at a disreputable address, to be punished. After complaints against the women living at Krakow street, for example, the Archdeacon made it known that the women could be 'extirpated' from their homes on pain of excommunication. ${ }^{47}$ Two parish priests at St. Gallen were authorised by the Archdeacon to 'correct and repel' the suspect women who had been spending time in local (presumably beer) cellars where drinking contests took place. Notably, the houses in which these debaucheries happened were owned by two named men: Wenceslaus the Bailiff and Johlinus the passenger (?). Neither man is

$45^{\circ}$ There the master archdeacon of Prague commanded the same parish priest, to solicit the citizens and neighbours and parishioners of said parish, as he is in it, that said women be driven from the aforesaid parish.' ('Ibidem dominus archidiaconis Pragensis mandavit ipsi domino plebano, ut solicitet cives et vicinos ac parrochianos dicte plebis, quantum in eo est, ut dictas mulieres de plebe sua predicta eiciant.') Ibidem, 69.

46 'There the master archdeacon commanded the same deponent parish priest, be granted the help and assistance [he was] seeking, that said women [Vela and Ela], as mentioned above and below, be expelled from the aforesaid parish.' ('Ibidem dominus archidiaconus predictus mandavit ipsi plebano deponenti, quarentus det opem et operam, ut dicte mulieres [Vela et Ela], de quibus supra, ex[s]tripentur cum adiotorio plebes anorum suorum, de quibus supra et infra, et expellat de plebe sua predicta.') Ibidem, 74.

47 'And the master Archdeacon commanded that the same parish priest, be granted the help and assistance extirpating said women on pain of excommunication.' ('Et dominus archidiaconis mandavit ipsi plebano, ut ipse det opem et operam ad dictas mulieres extripandas sub pena excommunicacionis.') Ibidem, 62. 
named by the Archdeacon as a specific target of correction. ${ }^{48}$ The houses were to be cleared of the suspect women with bad reputations, but it was assumed that the men who owned them could be 'corrected' by this gentle intervention.

Clearly then, the solutions that the Archdeacon provided in response to unwanted sexual activity were divided along strictly gendered lines. Laymen who were accused of sexual impropriety seem on the whole to have been ignored by the Archdeacon. Men were either thought to be tractable and corrected easily enough that their parish priests could intervene with them, or they were not worth correcting at all in the first place. In general, while the sins of these men were apparently worth gossiping about, they were evidently not worth attempting to modify. Boys, it would seem, were going to be boys. Yet, the fact that the Archdeacon did not prescribe punishment for the men named in these accusations is also interesting because it helps to explain why plaintiffs were somewhat comfortable gossiping about these men directly. They were able to name names in these instances because if the sins were not worth correcting, neither were they enough to ruin a man's name and reputation. These men may have been 'infamous' for their sexual misconduct, but that did not preclude them from participating in society fully. Gossip about them was therefore an acceptable part of life within a community, just as their poor behaviour was an accepted, if unwelcome, part of urban communal life.

The priests named in the documents, in contrast, received a greater amount of correction. The Archdeacon seems to have been more displeased when he learned that members of the clergy were sullying

48 Wenceslaus Perneri and Wolf said that in their parish there are certain suspect cellars, which scandalized men, the first of which is in the house of Wenceslaus the Chamberlin and in the house of John the passenger [?], in which beer is drunk, to which suspect women continuously come, about who there is a bad reputation. There the master archdeacon of Prague committed to the parish, to have greater respect [restored] in said infamous houses and if anyone knew how to correct it, to correct the commoners occupying it under pain of holy obedience.' ('Wenceslaus Perneri et Lupus ... dicunt ... quod in plebe eorum sunt alique celaria suspecta, de quibus homines scandalizantur, quorum primum est in domo Wenceslai camerarii et in domo Johlini vectoris, in quibus propinatu cervisia, ad que quasi continue solent intrare mulieres suspecte, de quibus est mala fama. Ibidem dominus archidiaconus Pragensis commisit plebano, ut maiorem respectum habeat ad dictas domos infames et si aliquere sciet corrigenda, corrigat et de plebe suare pellat sub pena sancta obediencie.') Ibidem, 110. 
their reputations with sexual misconduct. On the whole, it was fairly common for some sort of correction to be given to the wayward priests, though in some cases it was apparently not worth either dispensing or recording. In general, the suggested action was the extraction of a confession, a penance, and the promise of good behaviour in the future. Excommunication was a threat in these circumstances, of course. These threats help to underscore the fact that while the priests were escaping any direct action at that moment, their actions were nevertheless unacceptable. The greater frequency with which priests were punished seems once again bound to the fact that plaintiffs were more comfortable giving specifics about the accused. These sins were too great to be ignored, and moral hygiene had to be kept up. Indeed, plaintiffs tended to declare that they or their communities were 'scandalised' by sinful behaviour much more often in complaints about libidinous clergy members. Their anger was justified. Men of the cloth should have been holding themselves to higher standards. Further, if the gossip was incorrect, the plaintiffs could assuage their guilt with the knowledge that apparently running naked through the streets of Prague was not always sufficient to warrant censure from the Archdeacon. Such gossip was therefore more idle than it was malicious.

Those who truly felt the wrath of the Archdeacon and their communities were women. In particular, women who were seen to be running groups of sex workers were singled out for the greatest punishment. The aforementioned Mara, for example, was summarily excommunicated, while the man who resided with her and presumably also benefitted from the illicit brothel escaped punishment. While the other chastised women, Polka, Vela, and Ela, managed to avoid excommunication, it was intended that they be driven from their homes and communities. Similarly, the unnamed women on Krakow Street were to be expelled or excommunicated. The suspect women frequenting the beer cellars of well-connected men were to be driven out. Even if women were working in public brothels, they could not escape the attentions of the clergy, as Master Ulrich's attempts to reform the municipal Obora brothel show.

While moving these women on may have satisfied the locals who wished to see their social circles cleansed of sinful activity, it did little to reform the women themselves, or indeed Prague as a whole. Expelled 
from their homes, the women would have to find new places to live in a city with infamously expensive rent. Given the expense of living in the city, is improbable that their sudden homelessness would mean that they were able to find a different line of employment. Moreover, as the complaints against Domka show, simply finding a way to support oneself was not enough to guarantee that a community would welcome a woman, particularly if she chose to do so in the company of other women. For a woman to be seen as truly integrated into a community, she needed to have a place of residence and means of earning that were dependent on men, but not tied merely to their sexual gratification.

Moreover, many of the women in this position, as discussed before, had not come to be sex workers simply as a matter of choice. There was a very real chance that they were involved in the trade due to their debts which could not be ameliorated simply because a particular community did not approve. Their debts would follow them wherever they went, and indeed they were often tied specifically to their landlords. If the brothel keeper was forced to move, they would therefore simply have to move with them. For these women, leaving sex work was not a matter of repenting of their sins and finding a new line of work.

Even when one excludes the material considerations that the women in these accusations faced, the theoretical "redemption" of Prague's suspect women was unlikely. If they were willing to face excommunication, public revilement, and difficulty in attaining housing in order to be sex workers, then they could most probably continue to do so. It is doubtful that hounding them would change their opinion. Indeed, the way in which the punishments for these groups of women were meted out on a large scale shows that the archdeacon seems not to have been concerned with the salvation of or pastoral care for these women. Prague's sex workers were seen as an amorphous group and a geographical anomaly, as the complaints about the locations in which they worked show. These complaints and punishments that accompanied them were not made to correct individuals within a community. They existed to cleanse a community of an unwanted element.

As a result, harassment was the general prescription for women who failed to adhere to the customs surrounding prostitution in Prague. This also demonstrates the ways in which gossip and the grooming of one's 
social circle called for the exclusion of sinful women. Women did not have a place within Prague's parishes if they were not adhering to sexual norms, a fact underscored by the fact that when women did participate in illicit sex work and complaints were made, parishioners were careful to announce the date at which the woman or women in question began to work in their community. When these 'wandering' or 'scandalous' women arrived in a parish their presence was noted. ${ }^{49}$ The fact that these women were engaging in sex work meant that they were never going to be a part of the communities that they served; they were simply a serving them. As a result, it was not necessary to name them specifically or engage with them other than to move them out.

If these women were infamous enough that they could be named, the plaintiffs would do so and have them removed either physically from their own parish, or spiritually by means of excommunication from the Christian community as a whole. These women may have been seeking to build their own communities in which sex work, or at the very least 'suspicious' behaviour was the norm, but they had to do so within an overarching and theoretically Christian community that sought to eradicate their conduct, business, and presence. Gossiping about, reporting, and removing these women was a part of what made the parishes around them communities. They were the theoretical parasite that could be removed through social grooming.

Conversely, the ostracism aimed at these women belied the fact that their lives and livelihoods were a necessity of urban life. These women were providing a service that was in demand and which theologians admitted was crucial in maintaining public order. They, despite the complaints of the laity and the best efforts of the clergy, were a constant fixture. There would always be an ambient level of sexual commerce in any city. The best anyone could do was attempt to contain it to specific areas. The tension surrounding sex work and its acceptability in Prague seems to have been split down gendered lines when it came to both gossip and punishment. Laymen could participate in illicit sexual activities with women with few negative implications.

${ }^{49}$ For example, one complaint from the parish of St, Gastulus specifies that '...ad dotem sancti Leonhardi sepissime intrant muliere spublice et alie diverse etiam monachi et presbyterialii et faciunt ibidem conventicula eorum et commiscentur et, ut audivit, quod maxima scandal committuntur ibidem in dote et nequicie publice.' Ibidem, 85. See also the complaints against Polka, note 36. 
Priests would receive a slap on the wrist if they did so. Women would bear the brunt of the punishment for stepping outside of the accepted norms surrounding sex work. There was a place for licit sex work in Prague and in theory these women could choose to work in either the Obora or Hampáys brothels after expulsion from their homes for illicit prostitution. Yet, the sheer number of women implicated in the visitation protocol indicates that it would be impossible to fit them all in these two official brothels. Indeed, it shows that two brothels could not meet the desire of Prague's citizens for paid sex. What the visitation protocol makes clear is that while there was a clear and on-going demand for sex work in Prague, it was always hoped that it would happen outside of one's immediate parish and community.

\section{Conclusions}

Fourteenth-century Prague was a city that talked. Because of the stigma against gossip in medieval Europe and the theoretical damage that could be done to an individual's reputation through idle or malicious talk, it would be understandable to assume that Praguers would be reticent to share damning information about their neighbours. On the contrary, this study finds that Dunbar's theories of gossip and social grooming do a far better job of explaining the complaints to the Archdeacon than do the Church's proscriptions against idle talk. The individuals the Archdeacon interviewed saw themselves as tasked with overseeing the moral hygiene of their communities and were willing to break taboos about gossip if they felt that they could improve their immediate surroundings. If an individual could share information about what they saw as sinful behavior, it marked them as an involved and upright member not only of their local community, but Christendom as a whole. Thus, this concept of social grooming can help us to understand how these complainants were able to collect information from their neighbours, about their neighbours, and not be considered to be gossips.

As this study has shown, medieval Prague had a surfeit of information about sex work to be shared. There was no part of the city in which complaints about illicit sex were not recorded, though complaints vary from parish to parish. There seems to have been a greater likelihood that individuals would complain about illicit sex work 
taking place in their own parish rather than in what was perceived as a neighbouring one; this shows that there may have been a limit to which discussion of one's neighbours was acceptable. If sinful behaviour was outside of the remit of one's parish priest, private individuals seem to have been excluded from attempting to attract pastoral care from the archdeacon for sinful individuals.

When complaints were recorded, the presumption that gossip was a malicious tool that must be curbed to preserve the reputations of men again seems to not ring true in Prague. In fact, it is much more likely that if someone was the subject of a complaint about illicit sex work they would be named if they were a man, as is shown by the fact that only four women's names can be conclusively linked to sex work, as opposed to the multiple complaints about men listed here. Indeed, this case study includes every mention of any woman named for illicit sex work in the Archdeaconate protocol. The total of four named women is the same as the number of complaints about various men named Wenceslaus, selected from a pool of miscreant Wenceslauses, for this study. This is despite the fact that it was male fama that was thought to require protection from the sins of the tongue. Instead, what can be seen is that these men are named not to put them at a disadvantage due to lost reputation, but because they are nonetheless seen as integral parts of their communities, even if they are sinning. If men participate in illicit sexual activity they are still a part of their parish, and an intervention could theoretically bring them to salvation. More to the point, the individuals who named men in their communities as subjects of these complaints had a moral obligation to do so in order to offer these sinners a chance for redemption. As devout Christians, these plaintiffs were taught that all individuals were sinners, but through assiduous self-control and the pastoral intervention of the Church sin and personal failings could be curbed. It was for this very reason that the Archdeacon was undertaking this protocol. He needed to know exactly where his pastoral intervention should be applied, and thus had to appeal to individuals on a local level in order to gather this information. These plaintiffs were therefore participating in social grooming in the purest sense - they were using their knowledge to irradiate moral blemishes from their society. The naming of men involved in illicit sex was thus not about damaging reputations, but resuscitating them. 
The theoretical corrections that were advised for men who fell afoul of the Archdeacon bolster this idea. Men - even priests - who were known to be engaging in illicit sex were, in general, corrected by means of penance and promises for improved behavior in the future. It was not necessary to punish these men for their sins. Instead, they were given an opportunity to atone for them and once again join the universal Church. However, in most cases the sinful behavior of the men in question did not even warrant a response from the Archdeacon. Whilst these men were sinning, procuring sex in illicit circumstances apparently did not constitute much of a concern. More intervention seems to have been called for in cases where sin was compounded by the rank of the men in question. As a result, priests were more likely to be corrected for their sexual profligacy than average lay individuals. However, even in these cases correction was not always forthcoming. Why, then, should individual plaintiffs concern themselves with the fama of their compatriots? If the Archdeacon could not be bothered to intervene with individuals for their behavior, gossip about such subjects hardly constituted sinful behavior itself.

These same findings do not apply to women. In general, the women who Praguers complained about are not named, and no corrective actions are sought in order to redeem them. The women were not individuals to be intervened with, they are faceless groups living on disreputable streets, or plying their trade in bushes, churchyards, and beer halls. Indeed, these women, by virtue of their profession, are so indistinct that the localities in which they are working are named by plaintiffs. Their distinguishing features are the ways in which they earn a living, and the places in which they do so. This is also why the dates when sex workers take up residence in particular parishes is often noted. Their arrival even in a city undergoing massive demographic growth is notable because it is not about new community members taking up residence; it is a shift of the moral and physical landscape that they join. These women were not a part of their communities, they were a feature that community members accessed. By virtue of seeing to the sexual needs of their community, these women necessarily marked themselves as irrevocably outside of it. Once again, complaining about these women was thus not idle gossip, but social grooming. They were an irritant to be removed.

Because these women were not community members, the 
Archdeacon did not have to concern himself with providing restorative pastoral care to them. These faceless groups of women could be expelled and moved along. Little wonder then that these sex workers were derisively described as 'wandering'. They were moved from place to place as and when a community found that the nuisance they caused outweighed the benefit they received from having a local supply of commodified sex. Their salvation was not a concern for the upright citizens of Prague - simply their absence.

When a woman disrupted a community with her commercial activity to the point that her name became public knowledge, however, it was expected that the Archdeacon would involve himself in order to curtail her behavior. While named men either escaped notice altogether or received penance, women who were named before the Archdeacon were, in general, excommunicated. Their success with illicit sex work meant that they were not only excluded from their local community, but the community of Christian believers as a whole. Women who broke societal norms about sex work were beyond redemption and thus had to be weeded from society. There was no way that gossip about them could harm the individuals who engaged in it. Reporting on them was grooming not only local Prague society, but Christendom itself.

At the outset of this research, it was hoped that more information about the women who were accused of 'suspicious' behaviour would be found. Instead, there is far more written about the men who took part in suspicious behaviour with the women and walked away with little social stigma as a result. Illicit sex work marked women as outside of the communities that gossiped about them. It made them objects in a story about men's misbehavior and the masculine personal failings which could be rectified. The suspect women were not seen as community members to chastise and rebuke. Instead by breaking sexual customs they marked themselves as sufficiently 'other' that they could be cast out from their local communities and the communion of Christians. There was no need to provide details about these women because knowing them as individuals did little to prove their detractors as a part of their local community. Social grooming meant that they were irritants to be discussed and removed. Meanwhile, the men who consorted with them or lived with, organised, and profited from them would go about their lives more or less unmolested.

In the course of this research, what has emerged is a clear picture of 
a society with dueling motivations. Praguers did not want to be seen to be gossiping, but wanted to prove themselves as an integral part of their community and committed to its wellbeing. They did not want sex work to be occurring in their immediate communities, but knew it would, and believed it must, exist in any urban centre. They knew that men were interested in accessing prostitutes, but blamed the women for their availability rather than the men who demanded their services and at times helped provide it. They saw illicit sexual activity as a cause for punishment and removal from a community, but only if it was women who were doing it. On the whole, Prague's suspect women still seem to exist behind a lacuna, but as the existence of this study in and of itself proves, they are still nevertheless a subject for fascinating discussion.

\section{References}

\section{Primary Sources}

Hlaváček, Ivan and Zdeňka Hledíková, eds. Protocollum visitationis archidiaconatus Pragensisannis 1379-1382 per Paulum de Janowicz. archidiaconum Pragensem factae. Prague: Akademia, 1973.

Jenšovský, Fredericus [Bedřich], ed. Monumenta Vaticana res gesta Bohemicas illustrantia: edidit archivum terrae Bohemiae. Prague: Akademia, 1944.

\section{Secondary Sources}

Akehurst, F.R. P. "Good Name, Reputation, and Notoriety in French Customary Law." In Fama: The Politics of Talk and Reputation in Medieval Europe, ed. Thelma S. Fenster and Daniel Lord Smail, 75-94. Ithaca, N.Y. and London: Cornell University Press, 2003.

Bardsley, Sandy. "Sin, Speech, and Scolding in Late Medieval England." In Fama: The Politics of Talk and Reputation in Medieval Europe, ed. Thelma S. Fenster and Daniel Lord Smail, 145-164. Ithaca, N.Y. and London: Cornell University Press, 2003.

Břetislav, Ferdinand. Starožitnosti a památky zemè české [Antiques and monuments of the Czech lands]. Prague: Kober and Markgraf, 1860. Craun, Wedward D. Lies, Slander, and Obscenity in Medieval English Literature: Pastoral Rhetoric, and the Deviant Speaker. Cambridge: Cambridge University Press, 1997. 
Crossley, Paul, and Zoë Opačić. "Prague as a New Capital." In Prague: The Crown of Bohemia, ed. Jiři Fajt and Barbara Drake Boehm, 59-73. New York, New Haven, and London Yale University Press, 2005. Dignan, Patricia. Hellmouth and Villains: The Role of the Uncontrolled Mouth in Four Middle English Mystery Plays (PhD dissertation). University of Cincinnati, 1994.

Dunbar, R. I. M. "Gossip in Evolutionary Perspective.” Review of General Psychology 8.2 (2004): 100-110.

Graus, František. Chudina Městská v dobvě Predhusitské [The Urban Poor in the Pre Hussite Period]. Prague: Melantrich, 1949.

Hlediková, Zdeňka and Jana Zachová. Zivot Arnošta ₹ Pardubicpodle Valentina Krautwalda (Das Leben des Ernst von Pardubitzerzäblt von Valentin Krautwald). Pardubice: Východočeské muzeum, 1997. Janega, Eleanor. Jan Milič of Kromerrižz and Emperor Charles IV: Preaching, Power, and the Church of Prague (PhD dissertation: University College London, 2014).

Karras, Ruth Mazo. 'Prostitution in Medieval Europe.' In Handbook of Medieval Sexuality, edited by Vern L. Bullough and James Arthur Brundage, 243-260. New York and London: Routledge, 1996.

Klassen, John Martin. The Nobility and the Making of the Hussite Revolution. New York: East European Quarterly, 1978.

Mengel, David C. Bones, Stones, and Brothels: Religion and Topography in Prague Under Emperor Charles IV (1346-78). (PhD dissertation). University of Notre Dame, 2003.

Mezník, Jaroslav. "Der ökonomische Charakter Pragsim 14. Jahrhundert." Historica 17 (1969): 43-91.

Seibt, Ferdinand, ed. Kaiser Karl IV (1316-1378). Staatsman und Mäzen. Munich: Prestel, 1978.

Šusta, Josef. Karel IV. Za císařskou korunou, [Charles IV, For the Imperial Crown] Vol. II, Ceské Déjiny [Czech History]. Prague: Jan Laicher, 1948.

Tomek, Vladivoj, ed. Základy starébo mistopisu pražšébo [Foundations of the Topography of Old Prague], Vol. 3. Prague: Královská česká společnost nauk, 1866.

Trnek, Helmut. The Secular and Ecclesiastical Treasuries, Illustrated Guide, Kunsthistorisches Museum Vienna. Vienna: Kunsthistorisches Museum, 1991. 
Fig. 1

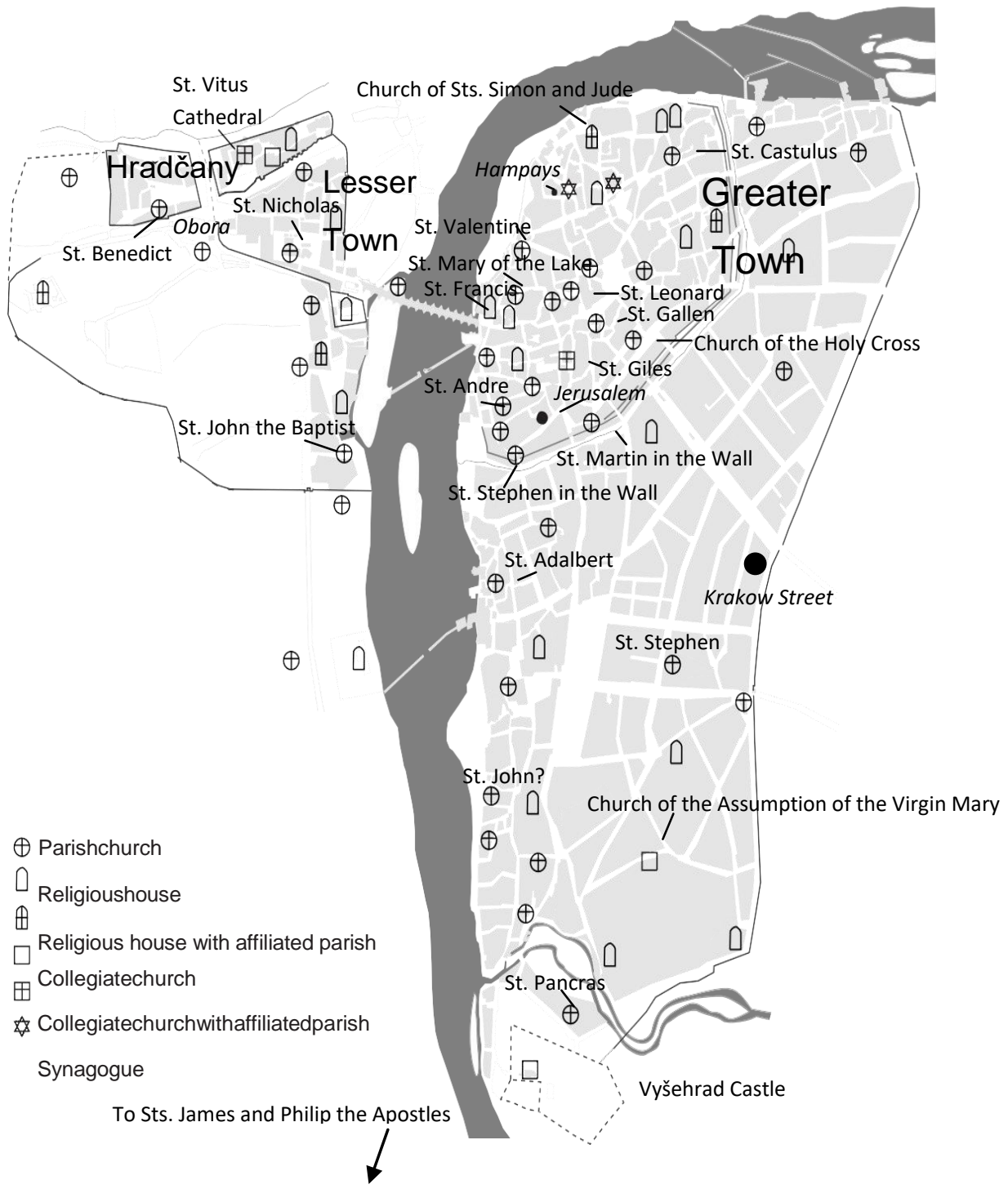

